\title{
PENGARUH PENERAPAN METODE QUANTUM LEARNING TERHADAP HASIL BELAJAR MATA PELAJARAN BAHASA INGGRIS
}

\section{Dwi Martine S.*}

\begin{abstract}
The purpose of this study is to find out the effects of quantum learning method to the learning achievement in English subject for the learning participants at the Community Learning Activities Center in Pisangan Lama area, East Jakarta. The study was conducted at Miftahul Jannah Community Learning Activities Center, Pisangan Lama, East Jakarta, for one semester, from August to December 2008. It observed the effects in cognitive, affective, psychomotor aspects to the learning participants of Package $C$. The method employed was experiment in which the researcher was directly involved. The data were collected from 40 Package C participants randomly selected as the samples out of 70 participants of Grade III. The experiment proved that there are significant effects of quantum learning method to the learning achievement in English subject for the learning participants at Miftahul Jannah Community Learning Activities Center, East Jakarta.
\end{abstract}

Keywords: out of school education, quantum learning, learning achievement

\begin{abstract}
Abstrak
Penelitian ini bertujuan untuk mengetahui pengaruh penerapan metode Quantum Learning di Lembaga PKBM. Dengan mengambil tempat di PKBM Miftahul Jannah, di daerah Pisangan Lama, Jakarta Timur selama satu semester terhitung dari Agustus sampai Desember 2008, penelitian ini mengamati pengaruh metode Quantum Learning terhadap hasil belajar peserta didik secara kognitif, afektif, dan psikomotor terhadap warga belajar. Penelitian ini menggunakan metode eksperimen dan peneliti sendiri terlibat langsung di dalam proses tersebut. Sebagai responden dipilih secara acak 40 orang warga belajar di kelas III Program Paket $C$ dari populasi yang berjumlah 79 orang. Hasil penelitian ini menunjukkan terdapat pengaruh signifikan penerapan metode Quantum Learning terhadap hasil belajar warga belajar kelas III Program Paket C di PKBM Miftahul Jannah untuk mata pelajaran Bahasa Inggris.
\end{abstract}

Kata Kunci : pendidikan luar sekolah, quantum learning, prestasi belajar

\section{PENDAHULUAN}

\section{Latar Belakang}

Pendidikan merupakan pondasi awal dari terbentuknya kualitas sumber daya yang menjadi aspek penting dalam menunjang pembangunan secara menyeluruh. Pentingnya pendidikan perlu ditanamkan sedini mungkin dalam setiap individu untuk menghasilkan sumber daya manusia yang berkompeten dan berkualitas sehingga menjawab tantangan globalisasi yang terus berkembang setiap saat. Pentingnya pendidikan usia dini yang melandasi setiap sistem pendidikan tercipta dengan standar-standar tertentu untuk mempersiapkan mental dan fisik sumber daya manusia khususnya di negara berkembang

\footnotetext{
* Alumni Jurusan PLS FIP UNJ
}

seperti Indonesia.

Menurut Undang-undang tentang Sistem Pendidikan Nasional Nomor 20 Tahun 2003 pasal 3 menyebutkan: "Pendidikan nasional berfungsi mengembangkan kemampuan dan membentuk watak serta peradaban bangsa yang bermartabat dalam rangka mencerdaskan kehidupan bangsa, serta bertujuan untuk mengembangkan potensi peserta didik agar menjadi manusia yang beriman dan bertaqwa kepada Tuhan Yang Maha Esa, berakhlak mulia, sehat, berilmu, cakap, kreatif, mandiri, dan menjadi warga yang demokratis serta bertanggung jawab".

Implementasi Undang-undang Nomor 20 Tahun 2003 tentang Sistem Pendidikan Nasional dijabarkan ke dalam sejumlah peraturan antara lain Peraturan 
Pemerintah Nomor 19 Tahun 2005 tentang Standar Nasional Pendidikan. Peraturan pemerintah ini memberikan arahan tentang perlunya disusun dan dilaksanakannya Standar Nasional Pendidikan yang dikutip dari Tim Redaksi Fokus Media, yaitu: "Standar isi, standar proses, standar kompetensi lulusan, standar pendidik dan tenaga kependidikan, standar sarana dan prasarana, standar pengelolaan, satuan pembiayaan dan standar penilaian pendidikan". Standar isi pada khususnya mencangkup lingkup materi dan tingkat kompetensi lulusan pada jenjang dan jenis pendidikan tertentu serta memuat kerangka dasar dan struktur beban belajar dan kalender pendidikan.

Berdasarkan Peraturan Menteri Pendidikan Nasional Nomor 82 Tahun 2008 Tanggal 11 Desember 2008, standar penilaian lulusan untuk kelas III SMU atau sederajat mata pelajaran Bahasa Inggris menjadi 5,5 . Ujian nasional yang dilaksanakan pada bulan April 2008 menjadi sorotan oleh para pengembang pendidikan terutama dalam pencapaian standar penilaian yang cukup tinggi untuk diraih tiap peserta didik yang mengikuti pendidikan formal maupun nonformal.

Oleh karena itu, pemerintah berupaya untuk meningkatkan aspek kehidupan terutama kualitas SDM di sektor pendidikan dalam bahasa Inggris. Tentu saja sektor pendidikan dituntut untuk memenuhi kebutuhan dalam semua bidang, tidak terkecuali untuk mata pelajaran Bahasa Inggris. Dalam penyelenggaraan standar isi terutama dalam hal kurikulum beberapa kekurangan masih sering terlihat dalam kegiatan belajar mengajar, salah satunya adalah penggunaan metode pembelajaran yang lebih banyak menekankan pada kognitif saja.

Tentu saja hal itu akan berdampak kepada kurang optimal dalam memahami secara utuh pembelajaran Bahasa Inggris yang diberikan. Metode-metode yang seharusnya digunakan untuk menunjang mata pelajaran Bahasa Inggris berorientasi kepada metode pendekatan suara sehingga tidak hanya mengarah kepada kognitif saja. Richards (1996) mengemukakan "Learning as models for language teaching, emphasized the importance of meaning in learning".

Lembaga Pendidikan Luar Sekolah menawarkan pendidikan yang melengkapi atau sebagai pengganti pendidikan formal dengan fungsi yang sama, yaitu menciptakan output yang sama unggul atau bahkan lebih baik dari pendidikan formal, tetapi dengan jangka waktu yang lebih pendek dan dengan materi yang lebih banyak, namun praktis, khusus, dan tentunya dengan strategi yang tepat untuk menghubungkan kedua hal tersebut.

Salah satu lembaga yang bergerak di bidang
Pendidikan Luar Sekolah (nonformal) dan diminati oleh sebagian besar masyarakat adalah PKBM (Pusat Kegiatan Belajar Mengajar) yang merupakan gabungan program kelompok belajar dan program life skill dalam mencapai tujuan Pendidikan Luar Sekolah. Perbedaan yang muncul menyebabkan kesulitan bagi pendidikan nonformal khususnya PKBM ini untuk melakukan proses yang sama dengan pendidikan formal dalam proses belajar mengajarnya, walaupun keduanya dituntut untuk menghasilkan output dengan standar penilaian kelulusan yang telah ditetapkan oleh Peraturan Menteri No. 82/2008. Fakta yang berasal dari realita yang ada di PKBM tersebut ditunjang dengan adanya karakteristik peserta didik yang mengikuti program kelompok belajar Paket $\mathrm{C}$.

Metode pembelajaran ataupun strategi dalam belajar merupakan salah satu faktor dalam pendekatan belajar yang sangat diperhatikan untuk menghasilkan hasil belajar yang optimal. Metode Quantum Learning adalah gabungan yang sangat seimbang antara bekerja dan bermain, antara rangsangan internal dan eksternal dengan konsep teori modalitas untuk mata pelajaran Bahasa Inggris yang dapat diterapkan dengan mudah dan dapat menghasilkan peserta didik yang berkualitas dengan penghayatan dan pemahaman yang efektif. Pada metode ini, lingkungan belajar yang tepat dapat diciptakan dengan suasana belajar yang nyaman dan santai. Penggunaan musik supaya terasa santai dan terjaga serta siap untuk berkonsentrasi. Menciptakan suasana dan menyesuaikan hati dengan berbagai jenis musik. Menggunakan pengingat audio visual untuk mempertahankan sikap positif dan menguatkan interaksi dengan lingkungan.

Seiring dengan kenyataan tersebut, merupakan tantangan yang sangat berat bagi pendidik dalam menentukan peningkatan hasil belajar. Oleh karena itu, peneliti sangat terdorong untuk mengadakan penelitian eksperimen dengan menggunakan Metode Quantum Learning pada proses pembelajaran Bahasa Inggris kelas III Program Paket C pada PKBM Miftahul Jannah untuk melihat peningkatan hasil belajar akibat pengaruh penerapan metode tersebut sehingga menghasilkan output yang optimal.

\section{Perumusan Masalah}

Berdasarkan identifikasi serta pembatasan masalah di atas, peneliti memfokuskan permasalahan sebagai berikut: "Bagaimana Pengaruh Penerapan Metode Quantum Learning Terhadap Hasil Belajar Mata Pelajaran Bahasa Inggris Peserta Didik Program Paket C Kelas III di PKBM Miftahul Jannah, Pisangan Lama Jakarta Timur?" 


\section{KAJIAN TEORETIS}

\section{Hakikat Pendidikan Luar Sekolah}

Menurut Sihombing (1999), Pendidikan Luar

Sekolah merupakan usaha sadar yang diarahkan untuk menyiapkan; meningkatkan; dan mengembangkan sumber daya manusia agar memiliki pengetahuan, keterampilan, sikap dan daya saing untuk merebut peluang yang tumbuh dan berkembang dengan mengoptimalkan penggunaan sumber-sumber yang ada di lingkungan.

Karakteristik dari Pendidikan Luar Sekolah, sebagai berikut.

1. Pendidikan Luar Sekolah sebagai pengganti dari pendidikan sekolah. Contohnya : Kejar Paket A, B, dan C.

2. Pendidikan Luar Sekolah dianggap sebagai supplement pendidikan sekolah. Contohnya : privat, les, dan training.

3. Pendidikan Luar Sekolah sebagai Complement dari pendidikan sekolah. Contohnya : kursus, try out, dan pelatihan

Tujuan diadakannya Pendidikan Luar Sekolah adalah melayani warga belajar supaya dapat tumbuh dan berkembang sedini mungkin dan sepanjang hayatnya guna meningkatkan martabat dan mutu kehidupannya, membina warga belajar agar memiliki pengetahuan, keterampilan dan sikap mental yang diperlukan untuk mengembangkan diri, bekerja mencari nafkah atau melanjutkan ke tingkat dan jenjang pendidikan yang lebih tinggi, serta memenuhi kebutuhan belajar masyarakat yang tidak dapat dipenuhi dalam jalur pendidikan di sekolah. Menurut Undang-undang Nomor 20 Tahun 2003 Pasal 26 Ayat 3 menyebutkan bahwa pendidikan formal meliputi pendidikan kecakapan hidup, pendidikan anak usia dini, pendidikan kepemudaan, pendidikan pemberdayaan masyarakat, pendidikan keaksaraan, serta pendidikan lain yang ditujukan untuk mengembangkan kemampuan peserta didik.

Sasaran dari pendidikan kesetaraan biasanya terdiri dari kelompok masyarakat dengan rentang usia 15-44 tahun yang belum tuntas wajib belajar Pendidikan Dasar 12 tahun, kelompok masyarakat yang membentuk komunitas belajar sendiri, serta penduduk yang terkendala ke jalur formal karena berbagai hal seperti letak geografis, waktu, potensi khusus, ekonomi, keyakinan ataupun masalah sosial, dan hukum.

\section{Hakikat Metode Quantum Learning}

Menurut Sudjana (2001), metode adalah suatu usaha atau cara yang disengaja dan terencana dalam penyampaian suatu proses pembelajaran guna mencapai suatu tujuan pembelajaran yang telah ditetapkan sebelumnya. Berdasarkan Kamus Besar Bahasa Indonesia, Quantum Learning merupakan terjemahan dari bahasa Inggris yang terdiri dari 2 kata, yaitu "Quantum" dan "Learning". Quantum merupakan terjemahan dari kata sesuatu yang dapat menghasilkan energi dan Learning berarti pembelajaran sehingga bila digabungkan maka didapat kesimpulan bahwa Quantum Learning adalah seperangkat metode dan falsafah belajar yang terbukti efektif untuk semua umur serta dapat menimbulkan energi dan motivasi dari peserta didiknya.

Metode Quantum Learning mencakup aspekaspek penting dalam program Neurolinguistik (NLP), yaitu suatu penelitian tentang bagaimana otak mengatur informasi. Program ini meneliti hubungan antara bahasa dan perilaku dan dapat digunakan untuk menciptakan jalinan pengertian antara siswa dan guru. Penggunaan teori modalitas berpedoman kepada karakteristik peserta didik, yaitu visual, auditorial, dan kinestetik.

Pertama, visual. modalitas ini mengakses citra visual yang diciptakan maupun diingat. Warna, hubungan ruang, potret mental dan gambar menonjol dalam modalitas ini. Modalitas ini memiliki ciri-ciri lebih suka membaca daripada dibacakan, mengingat dengan gambar, memperhatikan segala sesuatu, membutuhkan gambaran dan tujuan menyeluruh, serta menangkap detail apa yang dilihat.

Kedua, auditorial, modalitas ini mengakses segala jenis bunyi dan kata yang diciptakan dan diingat. Musik, nada, irama, rima, dialog internal, dan suara sangat menonjol pada modalitas ini.

Ketiga, kinestetik, modalitas ini mengakses segala jenis gerak dan emosi yang diciptakan ataupun diingat. Gerakan, koordinasi, irama, tanggapan emosional, dan kenyamanan fisik menonjol.

\section{Hakikat Hasil belajar Bahasa Inggris}

Hasil belajar merupakan kemampuankemampuan yang dimiliki oleh peserta didik setelah melakukan suatu proses belajar. Adapun yang dimaksud dengan hasil belajar Bahasa Inggris, yaitu tingkat penguasaan keberhasilan yang telah dikuasai oleh peserta didik. Setelah mempelajari materi pembelajaran Bahasa Inggris. Dalam hal ini, menurut Tarigan (1990) bagian yang perlu dievaluasi dalam pembelajaran Bahasa Inggris bukan hanya mencakup pronounciation (pengucapan), grammatical structure 
(struktur bahasa), dan vocabulary (kosakata), akan tetapi penilaian Bahasa Inggris juga perlu dilakukan terhadap yang mencakup listening (menyimak), reading (membaca), speaking (berbicara) dan writing (Menulis)".

Pendapat ahli Russell (dalam Tarigan, 1985) mengemukakan bahwa : "Menyimak adalah suatu proses kegiatan mendengarkan lambang-lambang lisan dengan penuh perhatian, pemahaman, apresiasi, serta interpretasi untuk memperoleh informasi, menangkap isi atau pesan serta memahami makna komunikasi yang telah disampaikan sang pembicara melalui ujaran atau bahasa lisan". Kegiatan mendengar terdapat dalam menyimak karena menyimak merupakan kegiatan awal seseorang untuk mendapatkan pemahaman seseorang tentang sesuatu.

Keterampilan berbahasa yang kedua adalah reading (membaca). Setelah peserta didik ditekankan untuk menyimak, sangatlah mudah bagi mereka untuk mengucapkan atau membaca kata-kata tersebut dalam bahasa Inggris.
Speaking (berbicara) yang dimaksudkan dalam keterampilan berbahasa khususnya bahasa Inggris, yaitu belajar untuk mengucapkan kata-kata atau kalimat dalam bahasa Inggris secara benar.

Keterampilan berbahasa yang terakhir, yaitu menulis (writing). Wright (2001) mengemukakan bahwa salah satu teknik untuk mengevaluasi kemampuan menulis serta untuk mengetahui kosakata yang dimiliki oleh seseorang adalah dengan cara membuat tes melengkapi kata dan kalimat.

Beberapa faktor-faktor yang harus diperhatikan peserta didik dalam pembelajaran Bahasa Inggris, yaitu (1) dapatmengerti tentang materi baru yang diajarkan, (2) dapat mengulang materi yang telah diajarkan, (3) dapat memilih kalimat atau kata yang benar dari pilihan yang disediakan, (4) dapat berlatih sesering mungkin, dan (5) harus dibantu untuk mengerti materi baru yang diajarkan.

\section{METODOLOGI PENELITIAN}

\section{Tujuan Penelitian}

Penelitian ini bertujuan untuk mencari tahu dan memperoleh data mengenai pengaruh penerapan metode Quantum Learning dalam mata pelajaran Bahasa Inggris kelas III Program Paket $C$ di sebuah Lembaga PKBM di daerah Pisangan Lama, Jakarta Timur.

\section{Lokasi dan Waktu Penelitian}

Lokasi penelitian ini ditempatkan di lembaga PKBM (Pusat Kegiatan Belajar Mengajar) Miftahul Jannah, Jl. Pisangan lama III/2B Pisangan Timur Kecamatan Pulogadung Jakarta Timur. Penelitian ini dilaksanakan pada semester ganjil tahun ajaran 2008/ 2009 pada bulan Agustus 2008 hingga Desember 2008.

\section{Metode Penelitian}

Metode yang digunakan dalam penelitian ini adalah metode eksperimen nyata dengan pendekatan kuantitatif. Menurut Suryabrata (1990), metode eksperimen nyata adalah metode yang digunakan untuk menyelidiki kemungkinan sebab akibat dengan mengenakan kepada satu atau lebih kondisi perlakuan dan membandingkan hasilnya dengan kelas kontrol di mana peneliti terlibat langsung di dalam prosesnya.

\section{Populasi dan Teknik Pengambilan Sampel}

Populasi dalam penelitian ini adalah seluruh peserta didik kelas III Program Paket $C$ di lembaga PKBM Miftahul Jannah yang berjumlah 79 peserta didik, rentang usia antara 17-20 tahun. Sampel data dalam penelitian ini, yaitu 40 orang peserta didik Program Paket $\mathrm{C}$ kelas III dengan mata pelajaran
Bahasa Inggris.

Teknik pengambilan sampel yang digunakan adalah random sampling, yaitu pengambilan sampel dari semua populasi yang dilakukan secara acak, tanpa memperhatikan strata dalam anggota populasi.

\section{Teknik Pengumpulan Data}

Teknik pengumpulan data berdasarkan definisi konseptual dan operasionalnya, mengenai hasil belajar peserta didik dapat dilihat dari skor benar yang diperoleh dari evaluasi belajar. Soal yang digunakan berpedoman kepada materi yang telah diberikan dan kisi-kisi instrumen berupa tes yang mengarah pada ranah kognitif, afektif, dan psikomotor.

\section{Instrumen Penelitian}

Untuk mendapatkan ketepatan data mengenai kisi-kisi instrumen yang telah dibuat, peneliti melakukan pengolahan data melalui penghitungan validitas yang dilakukan dengan menggunakan rumus korelasi Point Biserial $\left(r_{p b i s}\right)$. Dari 40 jumlah soal yang dibuat, tidak ada butir soal yang drop. Jumlah butir soal semua valid, yaitu 40 butir soal.

Reliabilitas yang dilakukan dengan menggunakan rumus Kuder-Richardson dan kriteria kereabilitasan sebuah instrumen digunakan pedoman menurut Balian, sehingga hasil koefisien reabilitas setelah soal yang valid diperhatikan adalah 0,946 atau dikategorikan Luar Biasa Bagus.

Untuk tingkat kesukaran atau proportional correct dinotasikan dengan P. Indeks kesukaran butir 
merupakan proporsi responden yang menjawab benar suatu butir soal dengan seluruh peserta tes indeks. Kesukaran butir soal berkisar antara 0 sampai dengan 1. Dari perhitungan analisis tingkat kesukaran butir soal, diperoleh $27,5 \%$ butir soal yang mudah, $60 \%$ butir soal yang sedang, dan $12,5 \%$ butir soal yang sukar.

\section{Teknik Analisis Data}

a. Pengolahan data awal untuk mencari rata-rata, median, modus, simpangan baku (standard deviasi), nilai maksimum, dan nilai minimum. Selanjutnya distribusi frekuensi divisualisasikan melalui tabel dan histogram. b. Pengujian persyaratan analisis, yakni uji normalitas dan homogenitas. Pengujian normalitas dilakukan dengan uji Liliefors. Uji homogenitas dilakukan dengan uji Fisher.

c. Menguji hipotesis penelitian dengan menggunakan pengujian kesamaan dua rata-rata : uji dua pihak, yaitu dengan uji-t. Rumus t tersebut dibandingkan dengan $\mathrm{t} 1$ - á, di mana t1- á didapat dari daftar distribusi t dengan peluang (1- á) dan $d k=(n 1+n 2-$ 2). Pengujian dilakukan pada taraf signifikansi á $=$ 0,05 .

\section{HASIL PENELITIAN}

\section{Deskripsi Data}

Karakteristik yang ditemukan oleh peneliti adalah mengenai pendidikan formal peserta didik, rentang usia, pekerjaan yang sedang digeluti oleh peserta didik dan karakteristik ruang. Kompetensi dasar yang dirancang pada kisi-kisi instrumen, silabus dan Rancangan Pelaksanaan Pembelajaran (RPP) mewakili lima komponen keterampilan berbahasa yang harus dikuasai oleh peserta didik yaitu structure, vocabulary, reading, listening, dan writing. Setiap komponen dicapai dengan dibantu oleh sarana yang berbeda sesuai dengan karakteristik peserta didik dan berprinsip pada teori modalitas.

Daftar Nilai Ujian Tengah Semester dan nilai Post test Mata Pelajaran Bahasa Inggris Kelas Eksperimen:

Tabel 1. Daftar Nilai UTS Post Test Mata Pelajaran Bahasa Inggris Kelas Eksperimen.

\begin{tabular}{|c|l|c|c||}
\hline \hline No & Nama Peserta Didik & Nilai UTS & Nilai Post test \\
\hline 1 & Adi Juni & 5.60 & 5.00 \\
\hline 2 & Agus Sutrisno & 6.00 & 7.50 \\
\hline 3 & Ahmad Fahmi & 5.40 & 7.00 \\
\hline 4 & Ali Nursyid & 4.80 & 7.25 \\
\hline 5 & Amrulloh & 4.40 & 6.75 \\
\hline 6 & Ani Rohmani & 7.00 & 5.00 \\
\hline 7 & Asnaeni & 6.40 & 7.25 \\
\hline 8 & Beni Febriansyah & 4.00 & 5.75 \\
\hline 9 & Dewi Wahyuningsih & 5.60 & 6.75 \\
\hline 10 & Elan Rustandi & 5.60 & 6.75 \\
\hline 11 & Fitriyani & 4.40 & 7.00 \\
\hline 12 & Ira Rahmi Rahayu & 4.80 & 7.00 \\
\hline 13 & Irmanto & 4.00 & 6.00 \\
\hline 14 & Liska Sari & 5.60 & 7.00 \\
\hline 15 & Markus Diaz & 4.40 & 8.75 \\
\hline
\end{tabular}

\begin{tabular}{||c|l|c|c||}
\hline \hline No & Nama Peserta Didik & Nilai UTS & Nilai Post test \\
\hline 16 & Miftah Farid & 3.20 & 7.50 \\
\hline 17 & M. Komarudin & 4.40 & 7.00 \\
\hline 18 & M.Taufiq Ramadhan & 4.00 & 7.25 \\
\hline 19 & M.Teguh Pangestu & 3.60 & 7.25 \\
\hline 20 & Ngatib & 4.40 & 7.25 \\
\hline 21 & Risky Denovialin & 4.80 & 7.25 \\
\hline 22 & Rosalina Achmar & 5.20 & 6.25 \\
\hline 23 & Rudi Ihtiyar & 7.60 & 8.50 \\
\hline 24 & Saleh & 5.60 & 7.50 \\
\hline 25 & Santi Mega Sari & 4.40 & 6.75 \\
\hline 26 & Sartinah Sari & 5.20 & 7.25 \\
\hline 27 & Siti Rochmawati & 4.00 & 7.75 \\
\hline 28 & Suwarti & 6.00 & 6.25 \\
\hline 29 & Syahroni. B. & 6.40 & 5.00 \\
\hline 30 & Tasirih & 5.20 & 5.75 \\
\hline 31 & Teddy Haryanto & 3.60 & 6.75 \\
\hline 32 & Titi Mulyati & 3.20 & 6.50 \\
\hline 33 & Tri Purwanti & 4.40 & 7.25 \\
\hline 34 & Triyono & 4.80 & 7.25 \\
\hline 35 & Utami Febriani & 5.20 & 7.50 \\
\hline 36 & Warsini & 3.60 & 5.00 \\
\hline 37 & Yuliana & 4.00 & 6.25 \\
\hline 38 & Yumita Sari & 3.20 & 7.00 \\
\hline 39 & Yuniar & 5.00 & 6.75 \\
\hline 40 & Zakaria & 6.40 & 7.75 \\
\hline
\end{tabular}

Dari tabel ternyata hampir seluruh peserta didik yang ikut di kelompok eksperimen memiliki hasil Ujian Tengah Semester yang relatif kecil sehingga tidak mampu dijadikan pedoman untuk proses pembelajaran berikutnya yang mengacu kepada Ujian Akhir Nasional yang memiliki standar penilaian kelulusan dengan nilai di atas 5,5. Di sisi lain hanya 4 orang yang tidak berhasil mencapai standar penilaian kelulusan dengan menggunakan metode Quantum Learning dan 2 orang 
di antaranya mengalami penurunan, hal tersebut disebabkan oleh faktor ketidakhadiran, keterlambatan, dan ketidakseriusan dalam mengikuti proses pembelajaran.

Penerapan metode Quantum Learning pada mata pelajaran Bahasa Inggris kelas III Program Paket C memiliki keunggulan dalam mencapai kompetensi dasar Listening sebesar 70,94\% dengan skor 227 yaitu mampu memahami dan menyimak instruksi serta informasi mengenai materi yang telah diajarkan oleh peserta didik. Structure sebesar $69,06 \%$ dengan skor 221 , vocabulary sebesar $66,88 \%$ dengan skor 214 , reading sebesar $69,38 \%$ dengan skor 222 dan yang paling kecil mencapai tujuan kompetensi dasar adalah writing sebesar 63,44\% dengan skor 203.

Berikut ini merupakan perbandingan hasil post test kelas eksperimen dan kelas kontrol :

Tabel 2. Perbandingan Hasil Post Test Kelas Eksperimen dan Kelas Kontrol

\begin{tabular}{|l|c|c||}
\hline \multicolumn{1}{|c|}{ Keterangan } & $\begin{array}{c}\text { Kelas } \\
\text { Eksperimen }\end{array}$ & $\begin{array}{c}\text { Kelas } \\
\text { Kontrol }\end{array}$ \\
\hline Rerata & 27.2 & 19.69 \\
\hline Median & 28 & 20 \\
\hline Modus & 29 & 17 \\
\hline Nilai Maksimum & 35 & 25 \\
\hline Nilai Minimum & 20 & 13 \\
\hline Jumlah \\
responden
\end{tabular}

\section{Hasil Penelitian Kelas Eksperimen}

Tabel 3. Daftar Penyebaran Kelas

\begin{tabular}{|c|c|c|c|c|}
\hline \multirow{2}{*}{ No } & \multirow{2}{*}{$\begin{array}{c}\text { Interval } \\
\text { Kelas }\end{array}$} & \multirow{2}{*}{$\begin{array}{c}\text { Titik } \\
\text { Tengah }\end{array}$} & \multicolumn{2}{|c|}{ Frekuensi } \\
\hline & & & Absolut & Relatif \\
\hline 1 & $20-22$ & 21 & 5 & $12.5 \%$ \\
\hline 2 & $23-25$ & 24 & 6 & $15 \%$ \\
\hline 3 & $26-28$ & 27 & 12 & $30 \%$ \\
\hline 4 & $29-31$ & 30 & 15 & $37.5 \%$ \\
\hline 5 & $32-34$ & 33 & 1 & $2.5 \%$ \\
\hline 6 & $35-37$ & 36 & 1 & $2.5 \%$ \\
\hline & Jumlah & 40 & & $100 \%$ \\
\hline
\end{tabular}

Mengacu pada tabel di atas, didapat jumlah responden yang berada pada kelas rata-rata adalah 15 responden atau 37,5\%. Responden yang mendapat hasil tes di bawah rata-rata berjumlah 23 responden atau $57,5 \%$. Sedangkan responden yang mendapat hasil test di atas rata-rata sebanyak 2 responden atau $5 \%$. Responden yang menjawab dalam interval 1 adalah 5 orang, interval 2 adalah 6 orang, interval 3 adalah 12 orang, interval 4 adalah 15 orang, ilnterval 5 adalah 1 orang, dan interval 6 adalah 1 orang.

\section{Hasil Penelitian Kelas Kontrol}

Tabel 4. Data Penyebaran Kelas

\begin{tabular}{|c|c|c|c|c|}
\hline \multirow{2}{*}{ No } & Interval & Titik & \multicolumn{2}{|c|}{ Frekuensi } \\
\cline { 4 - 5 } & Kelas & Tengah & Absolut & Relatif \\
\hline 1 & $13-14$ & 13.5 & 2 & $5.13 \%$ \\
\hline 2 & $15-16$ & 15.5 & 4 & $10.26 \%$ \\
\hline 3 & $17-18$ & 17.5 & 10 & $25.64 \%$ \\
\hline 4 & $19-20$ & 19.5 & 5 & $12.82 \%$ \\
\hline 5 & $21-22$ & 21.5 & 9 & $23.08 \%$ \\
\hline 6 & $23-24$ & 23.5 & 7 & $17.95 \%$ \\
\hline 7 & $25-26$ & 25.5 & 2 & $5.13 \%$ \\
\hline & Jumlah & & 39 & $100 \%$ \\
\hline
\end{tabular}

Jumlah responden yang berada pada kelas ratarata adalah 10 responden atau $25.64 \%$. Responden yang mendapat hasil tes di bawah rata-rata berjumlah 6 responden atau $15.39 \%$. Sedangkan responden yang mendapat hasil test di atas rata-rata sebanyak 23 responden atau $58.98 \%$. Sedangkan responden yang menjawab dalam interval 1 adalah 2 orang, interval 2 adalah 4 orang, interval 3 adalah 10 orang, interval 4 adalah 5 orang, interval 5 adalah 9 orang, interval 6 adalah 7 orang, dan interval 7 adalah 2 orang.

\section{Pengujian Persyaratan Analisis Data}

a. Pengujian Normalitas Kelas Eksperimen

Berdasarkan hasil pengujian diperoleh $L_{\text {hitung }}=0,1511$ dan $L_{\text {tabel }}$ untuk $n=40$ adalah 0,140. Dengan demikian, maka $L_{\text {hitung }}=0,1511>L_{\text {tabel }}=0,140$. Hal ini berarti bahwa data post test kelas eksperimen adalah normal.

b. Pengujian Normalitas Kelas Kontrol

Berdasarkan hasil pengujian diperoleh $L_{\text {hitung }}=0,1857$ dan $L_{\text {tabel }}$ untuk $n=39$ adalah 0,142. Dengan demikian, maka $L_{\text {hitung }}=0,1857>L_{\text {tabel }}=0,142$. Hal ini berarti bahwa data post test kelas kontrol adalah normal.

c. Pengujian Homogenitas Kelas Kontrol dan Kelas Eksperimen

Setelah diadakan pengujian didapat $F_{\text {hitung }}=1.227$ dan $F_{\text {tabel }}=3.07$. Dengan demikian, hal ini menunjukkan bahwa sampel varian homogen karena $F_{\text {hitung }} 1.227<F_{\text {tabel }} 3.07$. 


\section{Pengujian Hipotesis}

Pengujian hipotesis akan dilakukan dan menggunakan uji-t. Perhitungan dengan menggunakan rumus $u j i-t$ dengan syarat $\mathrm{H}_{0}: \mathrm{t}_{\text {hitung }}<\mathrm{t}_{1}-\left\langle\right.$, di mana $\mathrm{t}_{1}-\alpha$ didapat dari daftar distribusi $t$ dengan peluang (1- $\alpha)$ dan $d k=\left(n_{1}+n_{2}-2\right)$ dalam taraf signifikansi $\alpha=$ 0,05 atau $H_{i}: t_{\text {hitung }}>t_{1}-\alpha$ artinya rata-rata hitung selisih data kelas eksperimen dan kelas kontrol setelah di ujit lebih besar dari rata-rata hitung pada tabel distribusi $\mathrm{t}$, dalam hal ini $\mathrm{H}_{\mathrm{o}}$ ditolak dan $\mathrm{Hi}$ diterima ataupun sebaliknya. Peneliti mengajukan hipotesis dan menarik kesimpulan bahwa Ho ditolak dan Hi diterima.
Penarikan kesimpulan dengan diterimanya $\mathrm{Hi}$ setelah pengujian hipotesis adalah menunjukkan bahwa terdapat pengaruh penerapan metode Quantum Learning terhadap hasil belajar mata pelajaran bahasa Inggris kelas III Program Paket C di PKBM Miftahul Jannah.

Dari data tersebut didapat skor $\mathrm{t}_{\text {hitung }}=9,779>$ $t_{\text {tabel }}=1,67$ dengan taraf signifikansi $\alpha=0,05$, dengan demikian hipotesis yang diajukan oleh peneliti diterima bahwa terdapat pengaruh penerapan metode Quantum Learning terhadap hasil belajar mata pelajaran Bahasa Inggris kelas III Program Paket C.

\section{KESIMPULAN}

Berdasarkan penjabaran sebelumnya, peneliti mengambil kesimpulan bahwa proses pembelajaran Bahasa Inggris di PKBM Miftahul Jannah Kelas III Program Paket $C$ menggunakan metode yang berorientasi pada keseimbangan otak kanan dan kiri, dapat merangsang peserta didik untuk memunculkan materi-materi pelajaran kemudian memecahkan masalah secara bersama.

Metode Quantum Learning dalam pembelajaran Bahasa Inggris dapat dijadikan solusi tepat dalam meningkatkan standar penilaian kelulusan yang harus dicapai oleh peserta didik, yaitu dengan nilai di atas 5.5 pada tahun ini dalam mengikuti Ujian Akhir Nasional 2008/2009, karena hasil penelitian membuktikan hanya 4 orang yang tidak berhasil mencapai standar penilaian kelulusan dengan menggunakan metode Quantum Learning dan 2 orang di antaranya mengalami penurunan.

Letak kelebihan metode Quantum Learning dalam mewakili lima komponen pokok yang digunakan adalah pada peningkatan kompetensi dasar listening sebesar 70,94\% dengan jumlah skor nilai 227 dari 40 peserta didik dari 8 butir soal pada kompetensi dasar listening.

Pada hasil skor rata-rata (mean) post test yang didapat kelas eksperimen dengan skor 27,5 sedangkan mean kelas kontrol hanya 19,69. Hal ini membuktikan bahwa skor rata-rata (mean) postest peserta didik yang belajar mata pelajaran Bahasa Inggris di kelas eksperimen lebih tinggi dengan selisih 7,91 daripada kelas kontrol.

Kelas eksperimen memiliki skor dominan post test (skor yang banyak dimiliki) yaitu 29 dan kelas kontrol 17. Hal ini membuktikan bahwa dominan skor yang dimiliki kelas eksperimen lebih tinggi dibandingkan skor dominan kelas kontrol sehingga peserta didik di kelas eksperimen lebih memiliki skor dan tingkat pemahaman terhadap soal lebih tinggi dan berakibat terhadap peningkatan hasil belajar.

Jumlah responden kelas eksperimen yang berada pada kelas rata-rata 15 responden dengan frekuensi relatifnya $37,5 \%$ lebih banyak daripada jumlah responden di kelas kontrol pada kelas rata-rata yang berjumlah 10 responden dimana kesepuluh responter tersebut memiliki frekuensi relatif $25,64 \%$.

Jumlah responden yang berbeda di kelas eksperimen (40 orang) dan kelas kontrol (39 orang) tidak memengaruhi perhitungan normalitas data kedua kelas tersebut dan hasil perhitungan menyatakan bahwa masing-masing data dari kelas eksperimen $\left(\mathrm{L}_{\text {hitung }}=\right.$ $0,1511)$ dan kelas kontrol $\left(L_{\text {hitung }}=0,1857\right)$ berdistribusi normal dengan $L_{\text {hitung }}>$ dari $L_{\text {tabel }}(0,142)$.

Sampel yang didapat memiliki kesamaan atau dapat dikatakan variannya homogen, kemudian peneliti menguji hipotesis statistik hasil post test yang didapat dari kedua kelas tersebut dengan menggunakan uji-t pengujian kesamaan dua rata-rata : uji dua pihak.

Dari pengujian tersebut didapat hasil $t_{\text {hitung }}=9,779$ $>$ dari $t_{\text {tabel }}=1,67$, dengan perumusan hipotesis $H_{0}$ : $t_{\text {hitung }}<t_{1}$-á, di mana $t_{1}$-á didapat dari daftar distribusi t dengan peluang (1-á) dan $d k=\left(n_{1}+n_{2}-2\right)$ dalam taraf signifikansi á $=0,05$ atau $H_{i}: t_{\text {hitung }}>t_{1}-$ á Dengan lingkup perbandingan dari hasil yang diperoleh, dalam hal ini $\mathrm{H}_{0}$ ditolak sehingga diambil kesimpulan bahwa $H_{i}$ diterima di mana $t_{\text {hitung }}(9,779)>$ dari $t_{\text {tabel }}(1,67)$. Pengambilan kesimpulan ini berarti bahwa terdapat pengaruh dalam penerapan metode Quantum Learning terhadap hasil belajar mata pelajaran Bahasa Inggris peserta didik kelas III Program Paket C di PKBM Miftahul Jannah. 


\section{DAFTAR PUSTAKA}

Arikunto, S. (1996). Prosedur penelitian. Jakarta : Rineka Cipta.

DePorter, B. \& Mike H. (1992). Quantum learning, membiasakan belajar nyaman dan menyenangkan. Bandung: Kaifa Mizan.

Harmer, J. (1991). The practice of language. New York : Longman.

Koor, J. (1999). Growing up with english. Washington : Photo Disc.

Kurikulum 2004 standar kompetensi mata pelajaran bahasa Inggris SMU dan MA. Jakarta: Depdiknas 2004.

Kamus besar bahasa Indonesia: Edisi ketiga. Jakarta : Balai Pustaka 2005.

Miarso, Y. H. (1999). The development of learning organization. Surabaya: The Role of Open and Distance Learning.

Piaget, J. Cognitive Constructivisme. Diakses dari http:/ /pdts-unedu/theory/cognitve-html.

Reigeluth, C. M. (2000). What are instrutional strategies and theories. Diakses dari http://www.Sbs.Edu/ psy/winslow/psy.300/attitudes.

Richards, J. C. (1996). Approaches and methods in language teaching. New York: Cambridge Univercity Press.

Roestiyah, N. K. (1994). Didaktik metodik. Jakarta: Bumi Aksara.

Rusyam, T. (1993). Proses belajar mengajar yang efektif. Bandung: Bina Budaya.

Sihombing, U. (1999). Pendidikan luar sekolah dan masa depan. Jakarta: P. D. Mahkota.
Soeharto, I. (1998). Metode penelitian sosial. Bandung: PT Pemaja Rosdakarya.

Sudjana. N. (2002). Metode statistika. Bandung: Tarsito.

Sudjana, N. (2001). Penilaian hasil proses belajar mengajar. Bandung: Remaja Rosdakarya.

Sudjana, N. (2001). Metode dan teknik pembelajaran partisipatif. Bandung: Falah Production.

Sugiyono. (2002). Metodologi penelitian administrasi. Bandung: Alfabeta.

Sunarto, \& Agung H. (2002). Perkembangan peserta didik. Jakarta: Jendral Pendidikan Tinggi.

Suryabrata, S. (1990). Metodologi penelitian. Jakarta: PT. Raja Grafindo Persada.

Syah, M. (2002). Psikologi pendidikan dengan pendekatan baru. Bandung: Remaja Rosdakarya.

Tarigan, H. (1985). Pengajaran Kosakata. Bandung: Angkasa.

Tarigan, H. G. (1990). Menyimak sebagai suatu keterampilan berbahasa. Bandung: Angkasa.

Tim Dosen IKIP Malang. (1988). Pengantar dasar-dasar pendidikan. Surabaya: Usaha Nasional.

Tim Redaksi Fokus Media. (2005). Standar nasional pendidikan peraturan pemerintah nomor 19 tahun 2005. Bandung: Fokus Media.

UU RI no.20 tahun 2003 Tentang Sistem Pendidikan Nasional”. Jakarta: Tempo Interaktif, Rabu 31 Maret 2004.

Warkitri, H. dkk. (1987). Penilaian pencapaian hasil belajar. Jakarta: Karunika Universitas Terbuka.

Wright, A. (2001). Art and crafts with children. Oxford: Oxford Univercity Press. 